\title{
The World Congress on Mulla Sadra
}

The World Congress on Mulla Sadra was held May 22-27, 1999, in Tehran, Iran. Sponsored by the Islamic Republic of Iran, the Congress drew more than three hundred local and international speakers who presented papers on various aspects of the philosophy of Sadr al-Din Shirazi (d. 1640), commonly known as Mulla Sadra. The scope of the Congress, however, was not confined to the philosophy of Mulla Sadra; papers with other points of interest and focus were also presented. The Congress can be described as consisting of three concentric circles: the first, focusing exclusively on Sadrean studies; the second, ranging from Islamic philosophy to Sufism and kalam; and the third, extending to subjects as diverse as Muslims in China and Westem philosophy. In addition to Islamic thought, there was also a separate section on Westem philosophy, primarily focusing on analytic philosophy, in which many Westem scholars and philosophers participated.

The Congress began with a reading of a brief welcome speech by the director of the Congress, Ayatollah Muhammad Khamanei. The keynote address, and the concluding speech of the day, was delivered by Iranian president Muhammad Khatami, who talked about the importance of Islamic philosophy in general and Sadra's thought in particular for the future of Islamic world.

For the remainder of the Congress, each day, four simultaneous sessions were conducted in the Conference Hall of the Organization of Islamic Conference (OIC). The Islamic philosophy section, which was the main body of the Congress, was divided into four major subdivisions: Transcendent Philosophy of Mulla Sadra, Comparative Philosophy, Islamic Philosophy, and Gnosis and Sufism. Here the speakers focused on various aspects of the philosophy of Mulla Sadra, ranging from his ontology and epistemology to his eschatology and commentaries on Qur'anic verses. Mulla Sadra, who is considered to be one of the most important figures of the post-Avicennan Islamic philosophy, was both an original thinker and a first-rate historian of philosophy. With his notion of the primacy of being (asalat al-wujud) and his celebrated idea of substantial 
movement (al-harakat al-jawhariyyah), Sadra continues to draw the attention of scholars and philosophers from fields as diverse as theology and psychology. In this regard, it is interesting to note that the late Fazlur Rahman was the second person to write about Mulla Sadra after Seyyed Hossein Nasr had introduced him for the first time to the English speaking world - two Muslim thinkers of the century with irreducibly different points of view on various issues from the Qur'an and Hadith to Sadra's philosophy. The papers presented on Sadra's thought thus proved to be a rare opportunity to analyze and discuss Sadra's philosophical ideas as well as to exchange various points of views on the meaning and relevance of Islamic philosophy for many current issues.

There were also a number of comparative studies that analyzed Sadra's thought in relation to some Eastern and Westem philosophers. Notably, the scholars of Islamic and Western philosophy made interesting comparisons between Sadra's thought and that of Benedict Spinoza, Saint Anselm of Canterbury, Thomas Aquinas, Martin Hediegger, Alfred N. Whitehead, and even Sigmund Freud and Jean Piaget. And not surprisingly, a number of studies were devoted to the comparison of Sadra with such Islamic thinkers as Ibn Sina, Ibn al-Arabi, Ibn Rushd, Ibn Bajjah, and Hamza Fansuri. Since Sadra's philosophical work is a bold attempt to synthesize the earlier schools of Islamic thought, namely mashshai philosophy, the school of ishraq, and the school of Ibn al-Arabi, these comparative studies provided a stimulating framework of discussion in which one can witness the continuity of Islamic philosophy. Accordingly, this was a unique opportunity to observe and appreciate the internal dynamics of Islamic thought which, as these comparative studies show, is richer than it is ordinarily thought to be.

Although Mulla Sadra and his philosophy were the main focus of these four sessions, there were papers which covered other facets of Islamic intellectual tradition. These included exclusive studies on Ibn Sina, Ibn Bajjah, Baba Afdal, atomism in early kalam, and many other subjects. Some fell within the domain of Islamic culture and civilization such as Islamic arts and Muslims in China. Even though this wide range of topics might be criticized as a divergence from the main agenda of the Congress, it provided participants with the chance of facing different aspects of Islamic thought and culture to which they would not otherwise pay particular attention.

The Western philosophy section was divided into three parts: Issues in Western Philosophy; Philosophy of Science; and Logic, Language and 
Philosophy of Mind. Covering a wide area of Western philosophy these sessions were also held simultaneously in different conference rooms. As in the sections on Islamic philosophy, the speakers were Western scholars and philosophers from different countries and nationalities. In addition to presenting their work, they had also a unique chance of exchanging their ideas and points of view with the Muslim scholars.

Due to the considerable diversity of papers presented, the participants were able to choose sessions that addressed their special interests and fields of concentration. The name "World Congress" was a well-chosen one nearly all the major scholars of Islamic studies were present and there was ample opportunity to meet scholars from many different fields. During and outside the official program, the scholars were able to meet on various occasions such as the visit to the city of Shiraz, the hometown of Mulla Sadra. On this visit, the guests were taken to the world-famous Bagh-i Iram, Persapolis (Takht-i Jamshid), Madrasa-yi Khan where Sadra taught, and the tombs of Sa'di and Hafiz, two of the greatest names of Persian-Islamic literature. Besides seeing the marvels of Islamic art and architecture in Shiraz, the participants were also given several receptions, one of which was in Tehran hosted by Mrs. Mustafawi, the daughter of the late Ayatollah Khomaini, who warmly welcomed the participants.

Undeniablely, quality and quantity are in direct opposition. When one increases, the other decreases. This holds true for the otherwise quite successful Congress. The size of the Congress was seen by some (and rightly so) as too big to allow concentration and focus. And it is true that this congress was the largest conference ever held in the Islamic world on Islamic philosophy. As the participants presented their works of extremely diverse subjects and points of view, it was very hard to pinpoint a common agenda or even a theme for the sessions held simultaneously. One could say that the lack of harmony among the papers, which was an inevitable result of the huge size of the conference, was the only major flaw of the Congress.

In conclusion, the common feeling of the participants was that the organization of the Congress was very satisfactory given the magnitude of the event. Although Dr. Ghulam A'wani, the director of Anjuman-i Hikmat wa Falsafa, is to be congratulated for his indefatigable effort and refreshing smile, all the men and women who managed the Congress - from translation and hotel arrangements to transportation and food - deserve a warm thanks for their competence and dedication. 
NB: We were informed by the organization committee that the proceedings of the World Congress of Mulla Sadra will be published in the near future. This will certainly be an important contribution to the study of both Mulla Sadra and Islamic philosophy as these volumes will, God willing, reach scholars throughout the world. Lastly, there is a quarterly journal, Kheradnameh-e Sadra, published by Sadra Islamic Philosophy Research Institute (SIPRIn) which was also responsible for the organization of the Congress. The journal is published in Farsi with English summaries, and open to scholars working in the field of Islamic philosophy. For further information on the journal, the following address may be contacted: Mullahsadra@www.dci.co.ir.

Ibrahim Kalin Doctoral Student in Islamic Philosophy George Washington University 